\title{
The Use of Audio Visual Media In Improving The Quality Of PAI Learning In SMA Negeri City Of Bandung
}

\author{
Neneng Maemunah, Iim Wasliman, Deti Rostini, Sayid Muhammad Rifky Naufal \\ Nusantara Islamic University, Bandung, Indonesia \\ Nusantara Islamic University, Bandung, Indonesia \\ Nusantara Islamic University, Bandung, Indonesia \\ Nusantara Islamic University, Bandung, Indonesia \\ Email: nenengmaemunah101@gmail.com, iimwasliman@uninus.ac.id, detirostini@uninus.ac.id, \\ sayyidmuhammadrizkynaufal@uninus.ac.id
}

\section{ARTICLE INFO ABSTRACT}

Received

23 Juny 2021

Revision

1 July 2021

Approved

10 July 2021

\section{Keywords:}

Management

Learning Media

Audio Visual and

Quality of Student

Learning Outcomes

The background of the research is based on basic problems including audio-visual learning media as a support for the learning process in the world of education that is not optimal, lack of human resources and rapid technological developments, the readiness of the world of education itself must be able to balance and harmonize the system in optimizing the process of educational activities. The general purpose of this research is to find an overview of Computer-Based Learning Management in Improving the Quality of Student Learning Outcomes. The focus of the objectives is specifically to seek an overview: 1) Planning; 2) Organizing; 3) Implementation; 4) Supervision; 5) Problems; 6) Future Efforts; and 7 Results of Audio Visual Learning Media in Improving the Quality of PAI learning. Audio Visual Learning Media Theory is the basis of this research. The research procedure is determined by the determination of qualitative methods, through the process of: 1) Observation; 2) Interview; 3) Documentation. Which is developed through the triangulation process. The findings of the study of Audio Visual Learning Media Management in Improving the Quality of PAI Learning. Includes the process 1) Planning, its implementation in accordance with the development of computer-based learning is still within the scope of the process as the implementation of educational activities and has not been developed in full planning to support student learning outcomes; 2) Organizing, showing that the pattern of supporting human resources in the proportion of audio-visual learning media development is not in line with the developments currently needed. 3) Implementation, operation of audio-visual learning media only builds competence for the introduction of Information and Communication Technology in general without being developed with the application of the system in the educational environment itself 4) Supervision, specifically in building computer-based learning systems, mechanisms for implementing computer systems have not yet been built themselves in building student learning outcomes. 5) Problems, the readiness of Human Resources, facilities and systems for computer-based learning mechanisms themselves have not been developed; 6) Future Efforts, waiting for the policy to become the basis for determining the operational form in building a computer-

How to cite:

E-ISSN: Published by:
Maemunah, Neneng, Iim Wasliman, Deti Rostini, Sayid Muhammad Rifky Naufal (2021) The Use of Audio Visual Media In Improving The Quality Of PAI Learning In SMA Negeri City Of Bandung. Jurnal of Social Science 2(4). https://doi.org/10.46799/jss.v2i4.181 2721-5202 Ridwan Institute 
based learning process unit and 7) Results, which are the consequences of the pattern of supporting infrastructure facilities that are needed with a balance of supporting human resources in it and this has not been built in unit for implementing educational activities at the Research locus. In conclusion, optimizing the form of application of the use of audio-visual media in improving the quality of PAI learning. Students are needed in building the quality of student learning outcomes where information is developed through broad literacy development supported by balanced skills in utilizing and developing computer-based learning systems so that knowledge is built in developing knowledge. itself and the technology in it.

\section{INTRODUCTION}

Education as a process has two interrelated sides, education does not only include intellectual development, but is more emphasized on the overall personality development process. The ultimate goal of education is to create a complete Indonesian human who has knowledge and values of piety to God Almighty.

"Education is a conscious and planned effort to create a learning atmosphere and learning process so that students actively develop their potential to have religious spiritual strength, self-control, personality, intelligence, noble character, and skills needed by themselves, society, nation and state".

The role of the teacher as a motivator has a great contribution to students, it is important to improve the process and achieve learning objectives, namely students must have high motivation and one of the characteristics that indicate that students have high learning motivation is that they listen and participate actively in the learning process.

Then, education is seen as providing information through communication. Communication aims to convey a thought or message from one person to another. The relationship between the sender and the receiver is called communication. This means that the teaching and learning process is a communication that must be created by teachers and students. Through communication there is a transfer of messages conveyed by the teacher to students. There is an interaction in the teaching and learning process, in this interaction the teacher carries out teaching activities and students learn. In the teaching and learning process, students play a more active role while the teacher is only an intermediary in delivering material to students. Teachers are required to be able to convey the material well so that students easily accept the material.

The use of media in the learning process is very helpful for the success of learning. The use of learning media in the learning process can generate interest, motivation and stimulation of learning activities. Learning media according to Rossi and Breidle in (Sanjaya, 2019), are all tools and materials that can be used for educational purposes. According to (Arsyad et al., 2013), Learning media is anything that can be used to convey messages or information in the teaching and learning process so that it can stimulate students' attention and interest. Based on the above understanding, what is meant by learning media are facilities or tools used to facilitate students in receiving messages in the learning process by transferring knowledge that can stimulate students' thoughts, feelings, and willingness to learn.

If the learning process in the classroom still uses conventional methods, then the learning process will only provide information that may be easily forgotten. PAI learning that takes place in this way will certainly not be able to achieve the desired learning objectives. In connection with this problem, PAI learning outcomes are low both in the realm of attitudes, knowledge, and skills. Learning outcomes or achievements are the result of an interaction of act of learning and act of teaching (Dimyati, 2006).

According to Haryati (2007: 22) learning outcomes can be grouped into three domains, namely cognitive, affective, and psychomotor which explicitly these three domains cannot be separated. Benjamin S 
Bloom in (Dimyati, 2006), divides the three domains as follows (1) cognitive with regard to intellectual learning outcomes which consists of six aspects, namely knowledge/memory, understanding, application/application, analysis, synthesis, and evaluation, (2) affective with regard to attitudes consisting of five aspects, namely acceptance, participation, assessment and determination of attitudes, organization and formation of lifestyles, (3) Psychomotor with regard to learning outcomes of skills and the ability to act.

Islamic education is one of the subjects at every level of public schools. In the GBPP PAI public schools, it is explained that Islamic religious education is a conscious effort to prepare students to believe, understand, appreciate, and practice Islam. through guidance, teaching and/or training activities by taking into account the demands to respect other religions in the relationship between religious dimensions in society to realize national unity (Muhaimin, 2012: 7576).

The purpose of Islamic Religious Education is to "increase the faith, understanding, appreciation and practice of students about the religion of Islam, so that they become Muslim human beings who believe and fear Allah SWT. and have noble character in personal, social, national and state life. (GBPP PAI, 1994). From these objectives, several dimensions can be drawn that will be improved and targeted by Islamic religious education activities, namely (1) the dimensions of students' faith in the teachings of Islam; (2) the dimensions of understanding or reasoning (intellectual) as well as students' knowledge of the teachings of Islam; (3) the dimension of appreciation or inner experience felt by students in carrying out Islamic teachings; and (4) the dimension of its practice, in the sense of how the Islamic teachings that have been believed, understood, internalized or internalized by students are able to foster motivation in themselves to move, practice, and obey religious teachings and values in personal life as human beings who believe and fear Allah swt. and actualize and realize it in the life of society, nation and state (Mujib, 2015).

One of the main factors that support the success of PAI learning is that teachers can use audio visuals in the learning process so that they can increase students' motivation and learning achievement.

However, there is an assumption that PAI learning in schools has been carried out less varied and ancient, this is because in the learning process, teachers are less than optimal in utilizing available learning resources and learning media, learning is still teacher-centered, and the method used is the lecture method, This makes students feel bored and uninterested. As a result, students are not motivated in learning, it is characterized by various activities that have nothing to do with the teaching and learning process, such as many students being lazy to study, chatting with friends, sleepy, and doing assignments in other subjects, lack of ability to ask questions, lack of enthusiasm for learning. , lack of interest in reading, low response to answering questions, completion of practice assignments and homework not on time, in the end learning outcomes are low, both in the realm of attitudes, knowledge, and skills.

Based on the results of observations and seeing from the facts that the use of audio-visual media is suspected to have an influence in increasing students' motivation and learning achievement in PAI subjects. Starting from the assumptions described above, the authors are interested in researching with the title "Use of audio-visual media in improving the quality of pie learning at SMA Negeri Bandung (a case study at SMA 24 Bandung and SMA 3 Subang).

The problem of using audio-visual media in PAI learning is an unsolved problem in line with the complexity of environmental changes, both in terms of planning, implementation and assessment, so that it has an impact on student learning outcomes at SMA Negeri 24 Bandung and SMA Negeri 3 Subang.

\section{METHOD}

This research will use a qualitative approach, namely the research is carried out in natural conditions. (Sugiyono, 2010). And the nature of discovery so that it takes the analysis and constructing the object under study. Qualitative research (qualitative research) departs from the philosophy of constructivism which assumes that reality has multiple, interactive dimensions and an exchange of social experiences (a shared 
social experience) which is interpreted by individuals. (Sudjana, 2006). The reason for using this approach is that researchers intend to gain a deeper understanding of the use of audio-visual media in increasing motivation and learning achievement in PAI learning at SMA Negeri 24 Bandung and SMA Negeri 3 Subang.

\section{Data Collection Techniques \\ a. Observation}

Observations are observations made directly on the object of research, with observation a clear picture will be obtained. (Nasution, 1982) states that observations are made to obtain data in the form of factual, accurate and detailed descriptions of the field conditions of human activities and social situations, as well as the context in which the activities occur. In this case, observation is one of the data collection techniques by observing the use of learning activities using audiovisual media that is ongoing, and about how the performance of teachers in the school concerned. Observations are carried out directly in the hope of obtaining information and data about objective conditions.

\section{b. Interview}

Interview is a technique of
collecting
communication with data sources. The communication is done through verbal dialogue. In order for the interview to be effective, there are several stages that must be passed, namely: 1) introduction; 2) explain; 3) explain the interview material; and 4) Asking questions, (Yunus, 2010: 358). Interviews are one form of data collection carried out orally in face-toface meetings individually. This interview was conducted in private with the principal, vice head of curriculum, PAI teachers, and several students. The problems interviewed have been compiled by researchers through development based on research indicators related to the use of audiovisual media in SMA Negeri 24 Bandung and SMA Negeri 3 Subang.

\section{c. Documentation}

Documentation is a technique of collecting this data, because it wants to obtain data from respondents' words and documents related to the principal's leadership strategy in improving the quality of learning. Documentation technique is used to find out written data about the use of audio-visual media at SMA Negeri 24 Bandung and SMA Negeri 3 Subang through searching school documents, books, photographs, and various other literatures.

\section{Data Source}

Sources of data in this study are grouped into two, namely primary data sources and secondary data sources. Primary data sources are statements and actions from people who are observed or interviewed which are recorded through written notes or through recording and taking photos. The rest are secondary data sources such as writings/documentation, photos and statistics (Moleong, 2007). Primary data were obtained from informants, namely the Head of SMA Negeri 24 Bandung and SMA Negeri 3 Subang, PAI teachers, and students. Secondary data comes from existing official documents in the form of notes, pictures, photos and other materials that can support this research.

\section{Data Analysis Techniques}

Data analysis was carried out based on an interactive model. In this model data analysis, there are four interacting components, namely: data collection, data reduction, data presentation, conclusion drawing and verification. If the conclusion is deemed less stable, the researcher returns to collect data in the field, and so on so that it fits the cycle. The steps of the data analysis procedure are as follows: a. Data was collected by means of observation, interviews, and documentation studies. This is recorded descriptively, which is a record of what is seen, observed and experienced by the researcher himself.

b. Data reduction, During the data collection process, data reduction was carried out through a process of selecting, centralizing, simplifying, abstracting and translating the rough 
data obtained and written notes in the field.

c. The presentation of the data used in the study is in the narrative text of the field notes in order to limit a presentation as a summary of structured information in order to provide the possibility of drawing conclusions from taking action.

d. Drawing conclusions that are sought for the components presented, noting patterns, regularities, explanations, possible configurations, causal elements and proportions in the study.

\section{RESULTS AND DISCUSSION}

1. Planning the Use of Audio Visual Media in Improving the Quality of Student Learning Outcomes.

In this information age, educational organizations are developing dynamically and require innovation and creativity to increase public trust with excellent service. Several skills, both related to learning skills, managerial skills, operational skills, and believing skills must often be applied to support the implementation of education management which is imbued with six value systems (theological values, physical/physiological values, ethical values, aesthetic values, logical, and teleological value). Learning skills that cover the cognitive, affective, and psychomotor domains are closely related to the quality of the process and learning outcomes of students. Believing skill implies the essence of the learning climate, schooling, and education which refers to things that should be done (do) and should not be done (don't) that affect the quality of education services. Managerial skills and operational skills show managerial skills (including conceptual abilities and decision making) as well as technical skills needed in order to harmonize and manage quality aspects of learning skills and believing skills. This whole system of values and skills actually strengthens the dynamics of education.

Based on interviews conducted with Damis, said that all teachers at SMA Negeri 3 Subang are required to make learning tools, which contain annual programs, semester programs, distribution of time allocations, syllabus and lesson plans. This aims to determine the extent of preparation and competence possessed by a teacher in carrying out his duties as an educator. RPP can be used as a benchmark in carrying out learning activities that are in accordance with the objectives to be achieved. With a plan, learning activities will be easy to do in a systematic and structured manner. It can be said that the lesson plan is the first step made by the teacher before carrying out the learning process in the classroom.

Based on the author's observations, Islamic religious education teachers at SMA Negeri 3 Subang are more dominant in using the lecture method in the learning process, but if each material is carried out in this way, then the learning process will become monotonous and the target is only one-way without any feedback from learners. The impact of this method or method is that students become less active, feel bored and bored when learning Islamic religious education takes place. When learning Islamic religious education takes place there are some students who pay less attention to the material presented by the teacher, often ask for permission to leave class, are less independent when given an evaluation and are sometimes lazy to do homework.

After making a lesson plan (RPP), the next task of the teacher is to carry out the learning process according to the design made in the lesson plan. Based on the results of observations made by researchers, the teacher has prepared the RPP well, but in the implementation stage of learning sometimes it is not in accordance with what is stated in the RPP. Based on the observations made by the author, the implementation of Islamic religious education learning carried out by the teacher when entering the class starts from:

a) The teacher asks the students' attendance.

b) The teacher asks the students where the subject matter at the previous meeting was.

c) Asking questions to students related to the subject matter at the previous meeting. 
d) The teacher explains the learning objectives that must be achieved by the students.

e) Then the teacher explains the main learning material.

In the stage of the Islamic religious education learning process, the obstacle that usually occurs is when you want to use the LCD in displaying films/videos in the learning process, which is supported by Aisah Daud's statement through interviews which said that: the implementation of good learning should be in accordance with the lesson plans that have been made previously, but in practice it is often not in accordance with the lesson plans due to limited learning media, such as LCDs. So that the use of LCD becomes ineffective because it must be used interchangeably with other teachers who have the same lesson hours. To overcome this, the teacher diverts it by using only textbooks in explaining the lesson.

Evaluation in planning is needed on the principle of developing computerbased learning forms in building the quality of student learning outcomes. Traditional, conventional and digital skills must be built in a balanced way, the quality of skilled human resource development in this case is being able to develop a directed system with broad and basic knowledge. This evaluation should be the basic foundation in planning. The readiness of supporting staff and infrastructure is an absolute study that must be built and developed continuously. Rapid changes related to science and technology positively and negatively in the world of technology itself become a form that must be considered and planned, this evaluation confirms that the unit that is directed leads to the development of a form of understanding of scientific disciplines that is directed in the direction of developments that occur where potential Existing natural resources are a form of building a balanced educational process.

2. Organizing the Use of Audio Visual Media in Improving the Quality of Student Learning Outcomes.

Structural conventionally is still attached where the development of information and technology itself has not been managed fundamentally. In the organizational structure must build a real framework in balance with the developments and changes that occur. This consequence is a part where the organizational structural system itself is built with flexible principles. Where the basic concept is put forward that Learning and adaptation is achieved through monitoring uptime, listening to customers, monitoring the market, collecting and analyzing data, creating and disseminating knowledge, and making decisions.

This shows that every process development will be balanced with changes in both the policy basis, implementation and consequences that must be developed within the organizational structure itself. This development control shows that the organization dynamically builds a balance with all its environment and resources.

The results of the basic study of the results of observations and documentation show that the learning of Islamic religious education using the help of audio-visual media in a system that is needed at this time is a form that must be developed on a broad and continuous basis, a network system and a process of developing the principle of developing the value of determining the implementation system in the form of scope development. knowledge itself is structurally a part of the development of the underlying science. The significance of the results of the documentation, where the supporting information collected to develop a computer-based learning unit will show the scientific discipline. This component itself builds a section, where a variety of different abilities, many of which are not just skills, but a combination of behavior, skills, knowledge, work habits, character, character and critical understanding.

The basis for the development of Tupoksi itself must be built, where the structural development of the implementation of computer-based learning must be aligned with the structural conditions of the current implementation. Inequality in the form of development that converts the function of conventional systems to digital from the 
results of the study indicate that the basic difficulty is caused by the lack of a balance system in increasing organizational human resources in understanding the implementation of the digital system itself.

Policies are needed in building a work system organization and performance is needed. The scope of the educational work organization's capacity in policy is the key, where the success of computer-based learning itself becomes a part of organizational development efforts that are developed within the school environment itself. Organizing means creating a structure with integrated parts in such a way that learning is carried out properly in order to achieve learning objectives and make it easier for students to learn the material as well as make it easier for teachers to supervise and evaluate the learning process. In the process of organizing a teacher preparing and compiling: (1). Learning objectives to be achieved as a result of learning; (2). Materials and teaching materials to be delivered are adjusted to the time allocation provided; (3) choosing the approach, method, technique and strategy to be used in the learning process adapted to the material to be taught, for example by using a computer-based learning model so that the learning objectives set are easier to achieve; (4). media or teaching aids and resources that will be used to assist learning success; and (5) the evaluation pattern to be achieved to assess the extent to which students achieve competence in accordance with the goals set, the evaluations compiled include affective, cognitive and psychomotor assessments of students with the availability of a Computer-Based syllabus, in the form of lesson plans made by a teacher before entering class. This syllabus is used as a guide in teaching and conditioning the class as a space for learning activities, so that it is conducive and able to help achieve goals effectively.

3. Implementation of the Use of Audio Visual Media in Improving the
Quality of Student Learning
Outcomes. The use of Audio Visual Media (LCD) makes understanding of material that is still abstract becomes concrete in terms of increasing students' understanding. From interviews that have been conducted with one of the teachers of Islamic religious education stated that. "Audio Visual (LCD) media can increase students' understanding. However, this needs to be balanced with the readiness of the teacher as a facilitator in learning who will apply the media. In using audiovisual media, teachers do not completely transfer their roles and functions to this media, teachers still have to monitor how students understand when using these media.

From the results of the interviews, the authors conclude that the use of Audio Visual media makes students able to absorb the concepts contained in a certain material which makes students' understanding further increase by connecting the application of the principles learned by illustrating similar elements. In other words, the use of Audio Visual media in learning is better, than not using the concepts referred to in Q.S. Al Isra verse 84 Allah says:

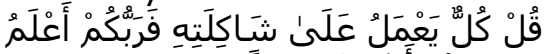

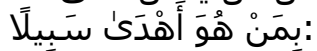

Say: "Each person acts according to his own circumstances". Then your Lord knows best who is more righteous in His way.

The verse above explains that every person who performs an action, they will do it according to their circumstances (including the surrounding natural conditions). This explains that in carrying out an action requires media so that the intended thing can be achieved, then a media in learning must be able to explain to students about the material they are studying. As for the Qur'an as a blessing and a giver of good news, if it is associated with media problems in the world of education, a media must be able to foster a sense of joy which further increases the interest of students in studying the materials presented.

4. Supervision of the use of audio-visual media in improving the quality of student learning outcomes.

The results of the study show that supervision itself is an inseparable part of a work process, in this case a broad description is built from the results of the 
research. In its implementation, supervision is built on the basis of efforts where control of the process of implementing Teaching and Learning activities in Islamic Religious Education with the help of Audio Visual Media in Improving the Quality of Student Learning Outcomes is built in planning in accordance with organizational management and rooting in principles, where supervision itself emphasizes the implementation process with integrity. mutual support between all components of existing resources to build work activities and their performance to achieve goals. Another step in the scope of this supervision is intended as a basis for developing evaluations for improving the education system that is built and implemented. While the results of other studies indicate that the purpose of the self-monitoring program is to control the implementation process carried out in Teaching and Learning activities in Islamic Religious Education with the help of Audio Visual Media in Improving the Quality of Student Learning Outcomes.

5. The Problem of Using Audio Visual Media in Improving the Quality of Student Learning Outcomes.

The professionalism of a teacher in managing the classroom can be seen when students are able to pay attention and are enthusiastic in accepting the lessons presented by the teacher and are able to develop skills in making the learning process more interesting if the necessary media and tools are not yet available. By providing media and tools that will be used, the learning process will certainly be more easily accepted by students, at least the teacher must start developing PAIKEM (Active, Innovative, Creative, Effective and Fun Learning).

Based on the author's observations, Islamic religious education teachers at SMA Negeri 3 Subang are more dominant in using the lecture method in the learning process, but if each material is carried out in this way, then the learning process will become monotonous and the target is only one-way without any feedback from learners. The impact of this method or method is that students become less active, feel bored and bored when learning Islamic religious education takes place. When learning Islamic religious education takes place there are some students who pay less attention to the material presented by the teacher, often ask for permission to leave class, are less independent when given an evaluation and are sometimes lazy to do homework.

Some of the problems above arise as a result of the lack of learning media used by teachers in the learning process. Not all problems in the learning process are teacher-centered, but the main reason is because school facilities are very lacking, so there are many obstacles experienced by Islamic religious education teachers in using media that are in accordance with the material to be delivered.

6. Efforts to Use Audio Media in Improving the Quality of Student Learning Outcomes.

Quality education is determined by several related components, starting from the input (input), process, and output (output), as well as with good management as well. Rachman stated that the management of improving the quality of education has characteristics that need to be understood by educational institutions that will implement it, namely; characteristics of an effective school (effective school), and the management of improving the quality of education which is the container or framework. Therefore, the following characteristics include inclusively the elements of an effective school, which are categorized into inputs, processes, and outputs.

Fattah stated that quality education must involve various components, namely: input, curriculum, human resources, various facilities, costs, and methods, as well as creating a conducive learning atmosphere. School management which is the authority of the principal, and class management which is the authority of teachers, functions to synchronize various inputs or synergize all components in the teaching and learning process. With regard to quality improvement management, it is necessary for principals who are willing to give authority to teachers to improve the quality of the teaching and learning process, are given 
the opportunity to make decisions, and are given greater responsibility in carrying out their duties as teachers. With the delegation of authority, initiative and sense of responsibility, teachers and other school staff can be more motivated to carry out a job better which in turn can produce quality education.

Teachers can enrich, expand and deepen a teaching and learning process by using learning media, especially when using media that stimulate more than one sensory organ. As with the use of audiovisual media, this media will greatly assist teachers in increasing understanding of abstract concepts and being able to arouse students' interest in learning. Where the advantages of this audio-visual media are that students can see directly and hear certain material presented by the teacher, with the help of audio-visual media the teacher is able to present material that cannot be explained only in words. As in the history of Islamic culture, the use of audio-visual media will be indispensable. It is also mentioned in Permendiknas No. 16 of 2007 concerning standards for academic qualifications and teacher competencies, it is stated that teachers must have the ability to use learning media and learning resources that are relevant to the characteristics of students and the subjects they are taught to achieve learning objectives as a whole.

7. Learning Outcomes of Audio Visual Media Improve the Quality of Student Learning Outcomes.

The priority policies are to help students develop optimally, which include: (1) providing school facilities that allow students to learn happily with adequate computer facilities and a teacher's workspace; (2) Provide rich learning media, which allows students to continuously learn by reading compulsory books, reference books, and reading books (including novels), as well as laboratory and library equipment, which allows students to learn to the level of enjoying learning.

The problem of educational equity is that there are still many school-age children who cannot enjoy formal education at school, while management issues involve all kinds of educational arrangements such as educational autonomy, bureaucracy, and transparency so that the quality and equity of education can be resolved properly.

Therefore, talking about the quality of education in Indonesia, it is necessary to look at several elements that influence it, such as: (1) curriculum, (2) educational content, (3) learning and evaluation processes, (4) teacher quality, (5) facilities and school infrastructure, and (6) textbooks. These six elements are interrelated in an effort to improve the quality of teaching and learning, which culminates in improving the quality of education.

Policies that have been built since the past decade have shown very high development and balancing in the scope of implementing Islamic religious education learning with the help of audiovisual media in improving the quality of student learning outcomes. through ICT support as a whole has not shown the scope of basic system development. In the management of competency learning there are several things that need to be considered, including:

a. Accessibility, namely students and teachers easily reach learning tools and resources.

b. Mobility, that is, students and teachers easily move from one place to another.

c. Interaction, which facilitates the interaction between teachers-students and students-students.

d. Variations in student work, which allows students to work individually/groups.

\section{Theological Foundation}

This foundation emphasizes the selection and use of learning media based on the characteristics of the learner and the media. This is based on the experience in which we get to know the various students. There are those whose learning styles are visual and auditive, and some are even audio-visual. Well, from that learning style we can understand in the selection of learning media (Jennah, 2009). Thus, learning media has three roles, namely the role of attracting attention (intentional role), the role of communication (communication role), and the role of memory / storage (retention 
role). (Rosyidah, 2009). In school learning, a teacher can create an interesting learning atmosphere by utilizing creative, innovative and varied learning media, so that learning can take place by optimizing the process and oriented to learning achievement. The basis for using learning media in the teaching and learning process can also be found in the Koran. The Word of Allah swt. in surah al-Nahl verse 44.

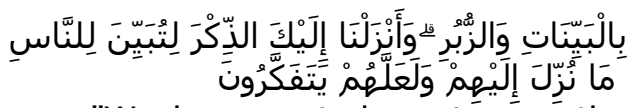

"We have sent down to you the Qur'an, so that you may explain to mankind what has been revealed to them and so that they may think about it."

The higher technological developments and the development of human civilization create increasingly complex problems in humans, the more complex human problems are, so they are required to be more prepared in preparing for various possibilities that occur, mental readiness is strongly emphasized here, namely how humans always surrender and accept whatever God gives. SWT, because we know that he will give the best for his servants.

\section{Philosophical Foundation}

The philosophical basis related to the focus of research on the use of audiovisual media to improve the quality of learning Islamic religious education in upper secondary schools is based on philosophical constructivism. The essence of philosophical constructivism is that knowledge cannot be transferred or transferred, but is built or formed by the individual himself. Constructivism focuses on learning processes not on learning behavior. (Sadulloh, 2009). Students construct or form their understanding of the material being studied. Construction means building, in the context of educational philosophy, constructivism is an effort to build a modern cultured life structure. Constructivism is also the foundation of a way of thinking in the contextual learning process, namely: knowledge is created by humans through a piecemeal process where the results are expanded through a limited context.
A teacher in using learning media needs to pay attention to the philosophical foundation. This means that the use of media should be based on truth values that have been found and agreed upon by many people, both academic truths and social truths.

For example, the content of the message (subject matter) that is conveyed to students should be a truth that has been tested objectively, radically and empirically. Do not let the subject matter is still wrong, not good, and not beautiful delivered to students. For example, the teacher teaches about the history of Islamic culture (SKI) with material on the genealogy of the Prophet Muhammad. A teacher needs to check the historical truth of the genealogy before it is conveyed to students. This process is called the use of philosophical foundation in choosing content and learning media. The media used by the teacher also needs to be rechecked for truth and accuracy. The teacher who chooses the media that is not in accordance with the material to be delivered means that the media is not correct. Not good, and not beautiful means that the use of inappropriate media has not taken into account the philosophical basis (Santyasa, 2007).

\section{Theoretical Foundation}

\section{Audio Visual Media}

Audio-visual media is media that can only be heard, in the form of sound with various means of conveying sound both from humans and imhumans. The arguments related to sound as the source of the message can be taken from the words read, explain, tell, and other meaningful words.

According to Deni D, (2017:82)

The development of audio-visual education has had a major influence on educational technology. A more rapid development of audiovisual occurred after the second world war. Education practitioners believe there is an increase in learning outcomes through audiovisual media (Lange, 1968, Seatler 1990).

\section{Quality of Learning}

Fattah stated that quality education must involve various 
components, namely: input, curriculum, human resources, various facilities, costs, and methods, as well as creating a conducive learning atmosphere. School management which is the authority of the principal, and class management which is the authority of teachers, functions to synchronize various inputs or synergize all components in the teaching and learning process. With regard to quality improvement management, it is necessary for principals who are willing to give authority to teachers to improve the quality of the teaching and learning process, are given the opportunity to make decisions, and are given greater responsibility in carrying out their duties as teachers. With the delegation of authority, initiative and sense of responsibility, teachers and other school staff can be more motivated to carry out a job better which in turn can produce quality education.

\section{Learning Quality Indicators}

Conceptually, quality needs to be treated as an indicator dimension that functions as an indication or pointer in professional development activities, both related to the business of organizing educational institutions and learning activities in the classroom. This is necessary for the following reasons:

1) Student Achievement Increases

Student achievement that can be used as a benchmark for success in learning so far in religious education has prioritized cognitive (knowledge), affective (feel) and psychomotor (behavior) aspects.

2) Students are able to work together Learning needs a collaboration between students or students and teachers. With cohesiveness, a conducive and fun learning atmosphere will arise. Harmony needs to be maintained and maintained by embodying the following attitudes: (1) there is mutual understanding so as not to dominate each other, (2) there is mutual acceptance not to walk each other according to their own will, (3) there is mutual trust so as not to suspect each other, (4) the existence of mutual trust. respect and (5) love each other not to hate and envy each other.

3) There is Fun Learning

Fun learning is needed to help students absorb and understand the lessons that are absorbed by the teacher, because if students don't like learning, the subject matter will not make an impression on students. This fun learning usually uses a variety of methods and creates an interesting classroom atmosphere.

4) Able to interact with other subjects

The problems of worldly life are not only in religious matters, but more in worldly fields. In this case, religious education can be a solution for all fields as long as the learning of Islamic religious education carried out is able to interact with other subjects.

5) Able to Contextualize Learning Outcomes

Contextual learning is needed to familiarize and train students in socializing, collaborating and solving problems. Learning will be more meaningful when children experience what they learn for themselves, not knowing it.

6) Effective Learning in the Classroom and Empowering Students' Potential

The quality of learning must be improved to improve the quality of educational outcomes. On a micro level, strategies or approaches to learning are found that are effective in the classroom and empower students' potential.

7) Achievement of Curriculum Goals and Targets

Achieving the goals and targets of the curriculum is a task that must be carried out by teachers and students in each lesson. These goals and targets can be used as minimal or maximum goals that must be achieved depending on the ability of the school consisting of teachers and other elements who carry it out.

12. 2013 Curriculum Learning and Assessment

a. Learning 
In essence, teaching is not just conveying subject matter, but is also interpreted as a process of regulating the environment so that students learn. The meaning of teaching is often termed as learning. This implies that in the teaching and learning process students must be used as the center of the activity. This is intended to shape the character, civilization, and improve the quality of life of students. Learning needs to empower all potential learners to master the expected competencies. In addition to learning, in the world of education, the term learning is also known.

In the Qur'an it is explained in the letter Al-Ghaasyiyah: 17-20 as follows:

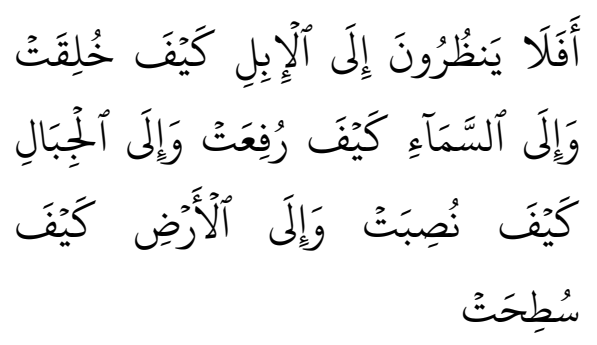

"Did they not see the camel how He was created, and the heavens, how they were exalted, and the mountains how they were set up, and how the earth was spread out?" (Surat alGhaasyiyah: 17-20)

In improving the quality of learning, we must pay attention to several components that affect learning, these components are as follows:

1. Students, covering the socioeconomic, cultural and geographical

environment/environment, intelligence, personality, talents and interests.

2. Teachers, covering educational background, work experience, teaching load, economic conditions, work motivation, commitment to work, discipline and creativity.

3. Curriculum.
4. Educational facilities and infrastructure, including teaching aids/practice tools, laboratories, libraries, skills room, counseling guidance room, UKS room and multipurpose room.

5. School Management, including classroom management, teacher management, student management, facilities and infrastructure, improvement of order/discipline, and leadership.

6. Management of the Learning Process, including teacher appearance, mastery of material/curriculum, use of learning methods/strategies, and utilization of learning facilities.

7. Fund Management, including budget planning, sources of funds, use of funds, reports and supervision.

8. Monitoring and Evaluation, including the Principal as a supervisor in his school, school supervisor and school committee as supervisor.

9. Partnerships, covering school relations with government agencies, relations with the business world and community leaders, and other educational institutions.

\section{CONCLUSION}

The use of Audio-visual Media in Improving the Quality of Islamic Religious Education, is to further develop knowledge related to science that continues to be built, so that it can provide support for the creation of a reliable and quality generation in science and technology that is a challenge now and in the future. . The quality of the school can also be seen from the complete infrastructure owned by the school. If the infrastructure is adequate, the output will also be good. It is proven by the existence of laboratories in schools that make students proficient in typing, while in schools that do not yet have these facilities, they have less ability and some even have no knowledge of computers at all. That means the means affect the quality of students. 
To improve the quality of education in the future we must pay attention to the following things:

a. Education is the responsibility of all citizens, not only the responsibility of the school. Consequently, all citizens have a moral obligation to save education.

b. Adequate facilities and infrastructure will improve the quality of education in teaching and learning activities.

c. Administration of facilities and infrastructure needs to be mastered by a leader whether it is the Dean/principal who is assisted by his staff so that the learning process runs in an orderly and smooth manner.

\section{REFERENCES}

Arsyad, Andi Anwar, Adam, Andi Muhammad, Amiruddin, Muhammad Dali, Ilyas, Faridha, Massi, Nasrum, \& St Maisuri, T. (2013). Comparison Of Local And Sistemic Interleukin-10 Levels On The Pregnant Women With Bacterial Vaginosis. Indian Journal of Dermatology, Venereology and Leprology.Google Scholer

Dimyati, Mudjiono. (2006). Belajar dan pembelajaran. Jakarta: Rineka Cipta.Google Scholer

Jennah, Rodhatul. (2009). Media Pembelajaran. Antasari Press.Google Scholer

Moleong, Lexy J. (2007). Metode penelitian kualitatif. Bandung: Remaja
Rosdakarya.Google Scholer

Mujib, Abdul. (2015). Implementasi Psikospiritual dalam Pendidikan Islam. Madania: Jurnal Kajian Keislaman, 19(2).Google Scholer

Nasution, Sukarjo. (1982). Metode Research (penelitian ilmiah).Google Scholer

Rosyidah, Umi. (2009). Penerapan model pembelajaran Contextual Teaching And Learning (CTL) untuk meningkatkan motivasi dan keaktivan siswa kelas VII SMP 3 Karanganyar.Goggle Scholer

Sadulloh, Uyoh. (2009). Filsafat pendidikan. Bandung: Alfabeta.Google Scholer

Sanjaya, Wina. (2019). Strategi pembelajaran berorientasi standar proses pendidikan.Google Scholer

Santyasa, I. Wayan. (2007). Model-model pembelajaran inovatif. Universitas Pendidikan Ganesha.Google Scholer

Sudjana, Nana. (2006). Dasar-dasar Proses Belajar Mengajar, Bandung: Sinar Baru. Algesindo Offset.Google Scholer

Sugiyono, Prof Dr. (2010). Metode penelitian pendidikan. Pendekatan

\section{Copyright holder:}

Neneng Maemunah, Iim Wasliman, Deti Rostini, Sayid Muhammad Rifky Naufal (2021)

First publication right:

Journal of Social Science

This article is licensed under: 